Articol

\title{
Acordarea unor sporuri diferite personalului medical și impactul asupra eticii profesionale ${ }^{1}$
}

\section{Cătălina-Georgeta DINU1,2*}

1 Universitatea Transilvania din Brașov, catalina.matei@unitbv.ro

2 Biroul teritorial Brașov al Instituției Avocatul Poporului Biroul Ombudsmanului

* Correspondence: catalina.matei@unitbv.ro

Citation: Dinu, C.G. (2021). Acordarea unor sporuri diferite personalului medical și impactul asupra eticii profesionale. Revista Etică și Deontologie, (1)1, 82-88, https://doi.org/10.52744/RED.2021.01.10

Publisher's Note: RED stays neutral with regard to jurisdictional claims in published maps and institutional affiliations.

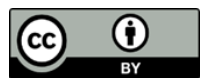

Copyright: (C) 2021 by the authors. Submitted for possible open access publication under the terms and conditions of the Creative Commons Attribution (CC BY) license (https://creativecommons.org/ licenses/by/4.0/].
Rezumat: Acordarea unor sporuri salariale diferite personalului medical, în funcție de specializarea medicală, conduce la inechități care se răsfrâng asupra actului medical, cu impact asupra eticii profesionale medicale. Aceste diferențieri au fost create prin reglementarea și aplicarea Regulamentului-cadru privind stabilirea locurilor de muncă, a categoriilor de personal, a mărimii concrete a sporului pentru condiţii de muncă prevăzut în anexa nr. II la Legea-cadru nr. 153/2017 privind salarizarea personalului plătit din fonduri publice, precum şi a condiţiilor de acordare a acestuia, pentru familia ocupațională de funcții bugetare "Sănătate şi asistență socială" - aprobat prin Hotărârea de Guvern nr.153/2018 - potrivit căruia sporurile acordate personalului medical creează diferențe mari de venituri între specialitățile medicale, aceste sporuri având cuantum între 5\% și 85\%. Acordarea diferențiată a sporurilor salariale, în funcție de specialitatea medicală, este lipsită de o justificare obiectivă și rezonabilă, iar amplitudinea diferențelor procentuale dintre sporuri nu se regăsește în alte state europene. Studiul analizează aceste aspecte legislative și are ca obiectiv propunerea unor modificări care să elimine inechitățile identificate.

Cuvinte cheie: spor salarial, specializare medicală, salariu de bază, etică

\footnotetext{
${ }^{1}$ Articol prezentat în cadrul Conferinței Internaționale Valorile Etice în Societatea Actuală - VESA 2021 (3-5 iunie).
} 


\section{Prezentare generală}

Legea nr. 153/2017, lege Cadru privind salarizarea personalului plătit din fonduri publice reglementează stabilirea unui sistem de salarizare pentru personalul din sectorul bugetar plătit din bugetul general consolidat al statului (Lege, 2017), inclusiv pentru personalul încadrat în unitățile sanitare publice.

Odată cu aplicarea acestei legi, au fost ridicate mai multe aspecte legate de modul în care salarizarea este stabilită pentru personalul medical, inclus în Anexa nr. 2 a legii, intitulată „Familia ocupațională de funcții bugetare Sănătate și asistență socială”.

$\mathrm{Cu}$ privire la sporurile pentru condiții de muncă, potrivit prevederilor art. 23 din Legea-cadru nr. 153/2017, sporurile de muncă, locurile de muncă și categoriile de personal, precum și mărimea concretă a sporului pentru condiții de muncă prevăzute în anexele nr. I-VIII se stabilesc prin regulamentul-cadru elaborat de către fiecare dintre ministerele coordonatoare ale celor 6 domenii de activitate bugetară, respectiv învățământ, sănătate, care se aprobă prin hotărâre a Guvernului, la propunerea fiecăruia dintre ministerele coordonatoare, cu avizul Ministerului Muncii și Justiției Sociale și al Ministerului Finanțelor Publice și cu consultarea federaţiilor sindicale reprezentative pentru domeniile de activitate.

Gestionarea sistemului de salarizare a personalului din unitățile sanitare publice, aflate fie în subordinea Ministerului Sănătății, fie în cea a unităților administrativteritoriale, se asigură de către ordonatorii principali de credite și de Ministerul Sănătății.

Prin Hotărârea nr. 153/2018 a fost aprobat Regulamentul-cadru pentru familia ocupațională de funcții bugetare „Sănătate și asistență socială” (Hotărâre, 2018).

\section{Aspecte de inechitate în actualul Regulament-cadru de aplicare a legislației salarizării în domeniul sănătății}

Reglementarea și aplicarea Regulamentului-cadru privind stabilirea locurilor de muncă, a categoriilor de personal, a mărimii concrete a sporului pentru condiţii de muncă prevăzut în anexa nr. II la Legea-cadru nr. 153/2017 privind salarizarea personalului plătit din fonduri publice, precum şi a condiţiilor de acordare a acestuia, pentru familia ocupaţională de funcţii bugetare "Sănătate şi asistenţă socială” aprobat prin Hotărârea de Guvern nr.153/2018, a condus la acordarea unor sporuri salariale în mod inechitabil, având în vedere că sporurile acordate personalului medical creează diferențe mari de venituri între specialitățile medicale, aceste sporuri având cuantum între 5\% și 85\%. De asemenea, se pune în discuție acordarea diferențiată a sporurilor salariale, în funcție de specialitatea medicală, ca fiind lipsită de o justificare obiectivă și rezonabilă, fără ca amplitudinea diferențelor procentuale dintre sporuri să fie regăsită în alte state europene.

În acest sens, exemplificăm faptul că, cel mai mic spor, de 5\%, este reglementat pentru personalul de specialitate medico-sanitar şi auxiliar sanitar din spitalele de urgență, potrivit Anexei nr. 8 din regulamentul-cadru. 


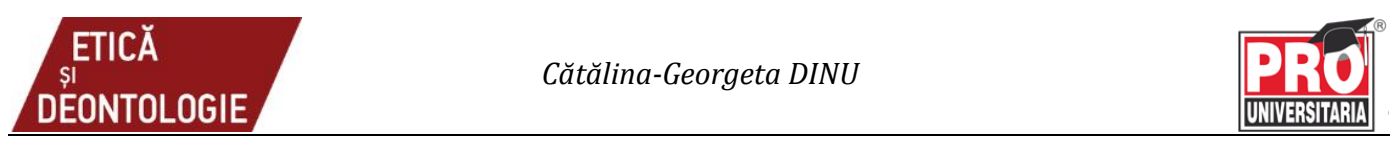

Un spor de de la $\mathbf{1 2 \%}$ până la $\mathbf{1 5 \%}$ din salariul de bază, este prevăzut pentru personalul care își desfăşoară activitatea în condiții deosebite cum ar fi stres sau risc, în condițiile art. 7 alin. (1) lit. h) de la cap. II din anexa nr. II la Legea-cadru nr. 153/2017, cu modificările şi completările ulterioare, fiind aplicabil pentru nu mai puțin de 29 de specialități medicale, printre care exemplificăm următoarele situații:

- personalul de specialitate medico-sanitar şi auxiliar sanitar din unități, secții şi compartimente cu paturi din specialitățile: traumatologie vertebro-medulară şi neuromotorie, chirurgie cardiovasculară, chirurgie cardiacă şi a vaselor mari, chirurgie vasculară, cardiologie intervenţională, chirurgie toracică, ortopedie şi traumatologie, chirurgie plastică - microchirurgie reconstructivă, chirurgie și ortopedie pediatrică, hematologie, chirurgie generală, urologie;

- personalul de specialitate medico-sanitar și auxiliar sanitar care asigură urgenţele medico-chirurgicale de gradele 0 și 1 până la restabilirea funcţiilor vitale ale pacienţilor, încadrat în spitalele judeţene de urgenţă şi în spitalele de urgenţă din centrele universitare;

- personalul de specialitate din secții şi compartimente cu paturi de medicină internă, pneumologie, cardiologie, recuperare cardiologică, diabet zaharat, nutriţie şi boli metabolice, gastroenterologie, recuperare respiratorie;

- personalul de specialitate medico-sanitar şi auxiliar sanitar din unităţi, secţii şi compartimente cu paturi de obstetrică-ginecologie; nefrologie; chirurgie orală şi maxilofacială.

Potrivit Anexei nr.1 la Regulament, personalul care îşi desfăşoară activitatea în condiții periculoase beneficiază de sporul prevăzut la art. 7 alin. (1) lit. a) de la cap. II din anexa nr. II la Legea-cadru nr. 153/2017, cu modificările şi completările ulterioare, și anume, un spor de până la $\mathbf{2 5 \%}$ din salariul de bază, pentru personalul de specialitate medico-sanitar şi auxiliar sanitar din unitățile, secțiile sau compartimentele cu paturi de boli infecţioase sau pentru cel din sala de nașteri/din secțiile și compartimentele cu paturi de neonatologie.

La polul opus, se află sporurile cuprinse între 50\%-85\% din salariul de bază, reglementate prin Anexa nr. 2 din Regulamentul-cadru, pentru personalul de specialitate medico-sanitar şi auxiliar sanitar din mai multe situații prevăzute expres, dintre care enumerăm:

- centrele pentru arşi;

- institutele de medicină legală şi din serviciile de medicină legală județene;

- serviciile de ambulanță;

- unitățile sanitare care participă efectiv la aplicarea măsurilor de limitare a unor epidemii deosebit de grave şi altele asemenea stabilite de Ministerul Sănătății şi declarate prin ordin. Pe durata stării de alertă și de urgență instituite, în condițiile legii, pentru situația de risc epidemiologic determinată de răspândirea virusului SARS-CoV-2 pe teritoriul României;

- secțiile sau compartimentele cu paturi în care sunt îngrijiţi bolnavi de HIV/SIDA, laboratoarele ce deservesc aceste paturi şi structura de spitalizare de zi HIV/SIDA şi din secțiile care au în custodie persoane private de libertate cu HIV/SIDA. 
În ceea ce privește personalul de specialitate medico-sanitar şi auxiliar sanitar din secții şi compartimente cu paturi la nivelul cărora se efectuează transplant de organe, țesuturi sau celule de origine umană, se observă faptul că Legea nr. 153/2017 art. 7 lit. b) stabilește un spor de până la 85\%, iar Anexa nr. 2 din Regulamentul-cadru, pct. B, pct. 13, sporul este de până la 75\% pentru aceeași categorie de personal.

În plus, menționăm faptul că, potrivit aceluiași Regulament, sporul reglementat este de la $\mathbf{3 5 \%}$ până la $\mathbf{5 0 \%}$ din salariul de bază pentru personalul de specialitate oncologică încadrat în:

- secții/compartimente cu paturi de oncologie medicală, oncologie pediatrică, radioterapie, hematologie oncologică;

- secții/compartimente cu paturi de hematologie care derulează programul de oncologie, pentru tratarea bolnavilor cu afecţiuni oncohematologice;

- în structura de spitalizare de zi din cadrul institutelor de oncologie, precum şi în

- structura de spitalizare de zi în specialitatea oncologie medicală şi radioterapie.

$\mathrm{Cu}$ toate acestea, de exemplu, pacienți cu afecțiuni oncologice sunt tratați și supuși intervențiilor chirurgicale în unități medicale cu secții sau compartimente cu paturi de obstetrică-ginecologie, astfel că, o determinare a cuantumului sporului acordat doar în funcție de criteriul secției/compartimentului conduce la inechități raportat la remunerarea personalului medical care desfășoară activitate similară, însă care este încadrată în secții/compartimente/unități diferite.

Afirmăm că acordarea unor sporuri salariale diferite personalului medical, în funcție de specializarea medicală, conduce la inechități care se pot răsfrânge asupra actului medical, și prin urmare cu impact asupra eticii profesionale medicale (Cod, 2012). Astfel pot fi aduse în fața comisiilor de etică (Salcă Rotaru, 2019) și în fața instanțelor de judecată o serie de situații conflictuale generate mai ales de utilizarea termenilor „pot fi acordate”, din care rezultă că nu e obligatorie acordarea acestor sporuri (Curtea de Apel Galați, 2020). De remarcat că în sistemul medical se regăsesc și instituții private, care pot face parte din sistem corporatist, unde se regăsesc, de asemenea, aplicabile principiile de etică, considerate pilon al reputației (Pantelică, 2008).

Așadar, este necesară modificarea Regulamentului-cadru aprobat prin Hotărârea de Guvern nr. 153/2018, însă aceasta se va realiza, cel mai probabil, ulterior punerii în aplicare a obiectivelor cuprinse în Programul de Guvernare 2020-2024, printre care este menționat și cel referitor la „demararea unei ample evaluări obiective asupra criteriilor care stau la baza salarizării în sistemul public, ca o condiție esențială a îmbunătățirii cadrului-legislativ" (Program, 2020).

Deci, doar ulterior modificării Legii nr. 153/2017 într-un mod substanțial sau a abrogării acestei legi și a intrării în vigoare a unui nou act normativ, vom putea asista și la elaborarea unui nou regulament cadru care să stabilească și sporurile corespunzătoare personalului medical.

Întrucât Hotărârea de Guvern nr. 153/2018 și Regulamentul-cadru aprobat prin această hotărârea reprezintă o legislație secundară care a fost elaborată în 
concordanță cu Legea nr. 153/2017 și pentru aplicarea acesteia, prevederile acestui regulament nu pot să depășească sau să fie contrare actului normativ principal.

Ca urmare, modificarea regulamentului-cadru impune o modificare inițială a legii, inclusiv din perspectiva diferențelor mari de venituri între specialităţile medicale create prin acordarea sporurilor pentru condiții de muncă.

\section{Memorandumul privind stabilirea personalului plătit din fondurile publice}

Referitor la necesitatea elaborării unor propuneri legislative privind modificarea legislației în domeniul precizat, Guvernul României a adoptat un Memorandum privind stabilirea personalului plătit din fondurile publice (Memorandum Guvernul României, 2021) (Memorandum, în continuare). Unul dintre principiile acestui memorandum este reprezentat de plafonarea sporurilor la $20 \%$ din salariul de bază, la nivel individual, precum și de revizuirea sistemului de acordare a sporurilor.

De asemenea, se menționează în cadrul Memorandumului, faptul că trebuie evaluată în mod obiectiv complexitatea muncii, fiind necesară corelarea între muncă şi nivelul de salarizare din sistemul public.

În acest sens, se propun o serie de principii care vor fi avute în vedere la elaborarea noului cadru normativ privind salarizarea personalului plătit din fonduri publice, printre acestea numărându-se:

(i) reanalizarea coeficienților de ierarhizare pentru fiecare familie ocupațională de funcții bugetare, cu respectarea raportului de 1 la 12, dintre cel mai mic și cel mai mare salariu de bază, și înmulțirea coeficienților cu salariul de bază minim brut pe țară garantat în plată în vigoare - 2300 lei;

(ii) revizuirea sistemului de acordare a sporurilor: sporurile pentru condiții de muncă la care expunerea la condiții de muncă este aceeași, indiferent de funcția deținută, se vor acorda în cuantum fix, ca spor de până la $25 \%$ din salariul de bază minim brut pe țară garantat în plată;

(iii) analiza tuturor categoriilor de sporuri, cu menținerea numai a celor cu adevărat relevante;

(iv) acordarea unui spor de performanță lunar, personalului care a realizat sau a participat direct la obținerea unor rezultate deosebite în activitatea instituției/ autorității publice sau a sistemului din care face parte, a participat la activități cu caracter deosebit, a efectuat lucrări cu caracter excepțional ori a avut un volum de activitate ce depășeşte în mod semnificativ volumul optim de activitate, în raport de complexitatea sarcinilor, în baza criteriilor stabilite de ordonatorul de credite;

În prezent, în sectorul bugetar se identifică o serie de discrepanțe salariale:

- unele apărute în urma aplicării legislației anterioare privind salarizarea personalului bugetar (Lege, 2009; Legea, 2010), iar

- altele identificate după data apariției Legii-cadru nr. 153/2017 privind salarizarea personalului plătit din fonduri publice, respectiv luna iulie 2017, ca urmare a modificărilor legislative succesive ale Legii-cadru în vigoare în 
Parlament, prin care unele categorii de personal au fost favorizate în raport cu celelalte categorii de personal din sectorul bugetar.

Cât privește plafonarea la 30\% din suma salariilor de bază, a sporurilor acordate personalului bugetar pe ordonator de credite, în prezent, există sectoare de activitate care sunt exceptate de la acest plafon de sporuri, ceea ce determină acordarea unui număr mai mare de sporuri pentru aceste categorii bugetare, în detrimentul altor categorii de personal bugetar care nu pot depăși acest plafon.

În acest sens, există excepții pentru instituțiile din sistemul sanitar și de asistență socială şi cele din sistemul de apărare, ordine publică şi securitate naţională, pentru care suma sporurilor, compensaţiilor, adaosurilor, primelor, premiilor şi indemnizațiilor, acordate cumulat pe total buget pentru fiecare ordonator principal de credite nu poate depăşi $30 \%$ din suma salariilor de bază, a soldelor de funcție/salariilor de funcție, soldelor de grad/salariilor/gradului profesional deținut, gradațiilor şi a soldelor de comandă/salariilor de comandă şi a indemnizațiilor lunare, după caz.

\section{Concluzii}

Deoarece determinarea sporurilor se face în raport cu salariul de bază se creează o situație discriminatorie, unele funcții beneficiind de un cuantum al sporurilor cu mult mai mare decât altele, cu toate că activitatea se desfășoară în aceleași condiții, iar expunerea la condiții periculoase sau vătămătoare este aceeași, indiferent de funcția deținută.

Scopul elaborării noului cadru normativ privind salarizarea personalului plătit din fonduri publice vizează eliminarea discrepanțelor salariale existente în prezent în sistemul bugetar, restabilirea ierarhiilor funcțiilor în cadrul domeniilor de activitate, precum și între domenii de activitate, precum și instituirea unui sistem de stimulare a performanței.

Propunerile formulate vor fi analizate și din punct de vedere al impactului financiar, prin raportare la plafoanele cheltuielilor de personal stabilite prin Legea nr. 14/2021 pentru aprobarea plafoanelor unor indicatori specificați în cadrul fiscal-bugetar pe anul 2021.

Față de cele prezentate, Memorandumul menționează că este necesar ca ministerele corespunzător familiilor ocupaționale de funcții bugetare să transmită în termen de 30 de zile, propuneri și observații de îmbunătățire a legislației privind salarizarea în domeniul de competență, în vederea reașezării politicilor salariale în conformitate cu principiile prezentate în acest Memorandum. Nu se știe însă dacă acest aspect a fost reținut de către ministerele de resort până în prezent și ce pași au fost făcuți ulterior Memorandumului prezentat.

Dincolo de aspectele strict juridice pe care le implică acest studiu, semnalăm impactul pe care salarizarea personalului din sectorul public îl are asupra eticii și deontologiei profesionale, acestea fiind într-o strânsă corelație.

În acest sens, considerăm că, mai ales în domeniul medical, comportamentul etic este un pilon al reputației cadrelor medicale, însă pentru îmbunătățirea acestui 
comportament, cât și a percepției pe care pacientul o are asupra acestuia, trebuie ca aspectul salarizării să fie în continuu îmbunătățit, mai ales cu privire la eliminarea efectivă a discrepanțelor salariale între categorii profesionale similare sau activități similare de profil.

Ca urmare, autoritățile administrației publice centrale trebuie să se mobilizeze și să trateze acest aspect cu prioritate, pentru o soluționare concretă și coerentă a acestei problematici, într-un interval de timp cât mai scurt.

\section{Referinte}

Cod, 2012. (2012). Codul de deontologie medicală, Colegiul Medicilor din România, aprobat prin Hotărârea nr. 2 din 2012, M.Of. nr. 298 din 7 mai 2012, modificat în 08.04.2016 și 06.01.2017, accesat la: http://legislatie.just.ro/Public/DetaliiDocument/137610

Curtea de Apel Galați, Personal bugetar. Spor pentru condiții deosebite de muncă în procent maxim. Neacordare, Revista Română de Dreptul Muncii nr. 5/2020, https://sintact.ro/\#/publication/151019411?cm=RELATIONS

Hotărâre, 2018. (2018). Hotărârea nr. 153 din 2018 pentru aprobarea Regulamentului-cadru privind stabilirea locurilor de muncă, a categoriilor de personal, a mărimii concrete a sporului pentru condiții de muncă prevăzut în anexa nr. II la Legea-cadru nr. 153/2017 privind salarizarea personalului plătit din fonduri publice, precum și a condițiilor de acordare a acestuia, pentru familia ocupațională de funcții bugetare „Sănătate și asistență socială", M.O. nr. 284 din 30 martie 2018, accesat la: http://legislatie.just.ro/Public/ DetaliiDocument/199240

Lege, 2009, (2009). Lege-cadru nr.330 din 5 noiembrie 2009 privind salarizarea unitară a personalului plătit din fonduri publice, M.Of. nr. 762 din 9 noiembrie 2009, accesat la: http://www.cdep.ro/pls/legis/legis_pck.frame

Lege, 2010, (2010), Legea-cadru nr. 284 privind salarizarea unitară a personalului plătit din fonduri publice, M.Of. nr. 977 din 28 decembrie 2010, accesat la: http://www.cdep.ro/ pls/legis/legis_pck.frame

Lege, 2017, (2017), Legea nr. 153/2017 - Legea cadru privind salarizarea personalului plătit din fonduri publice, M.Of. nr. 492 din 28 iunie 2017, accesat la: http://legislatie.just.ro/ Public/DetaliiDocument/190446

Memorandum Guvernul României (2021), Memorandum privind stabilirea personalului plătit din fondurile publice, https://sgg.gov.ro/1/wp-content/uploads/2021/04/MEMO-4.pdf

Pantelică, C., (2008), Comportamentul etic, pilon al reputației corporative, Amfiteatrul economic nr. 23/2008, p. 119, https://www.amfiteatrueconomic.ro/temp/Articol_333.pdf

Program (2020), Programul de Guvernare 2020-2024, accesat la: https://gov.ro/fisiere/pagini_ fisiere/Program_de_guvernare_2020_2024.pdf

Salcă Rotaru, C.M., (2019), The legal regime of the decisions of University Ethics Commissions in the current jurisprudential interpretation, http://webbut.unitbv.ro/bulletin/Series\%20VII/ Series\%20VII.html; 